\title{
High prevalence of Helicobacter pylori in saliva demonstrated by a novel PCR assay
}

\author{
C Li, P R Musich, T Ha, D A Ferguson Jr, N R Patel, D S Chi, E Thomas
}

Department of

Internal Medicine

(Gastroenterology),

James H. Quillen

College of Medicine,

East Tennessee State

University, Johnson

City, Tennessee 37684,

USA

$\mathrm{C} \mathrm{Li}$

$\mathrm{T} \mathrm{Ha}$

N R Patel

D S Chi

E Thomas

Department of Biochemistry

P R Musich

Department of Microbiology

D A Ferguson Jr

Veterans Affairs Medical Center, Johnson City, Tennessee

N R Patel

E Thomas

Correspondence to: Dr Eapen Thomas, Veterans Affairs Medical Center (111D), Johnson City, TN 37684, USA.

Accepted for publication 1 December 1994

\begin{abstract}
Aims-To investigate the prevalence of Helicobacter pylori in the saliva of patients infected with this bacterium.

Methods-A novel polymerase chain reaction (PCR) assay was developed to detect $H$ pylori in saliva and gastric biopsy specimens from patients undergoing endoscopy.

Results-Our PCR assay amplified a 417 base pair fragment of DNA from all 21 DNAs derived from $H$ pylori clinical isolates but did not amplify DNA from 23 non-H pylori strains. Sixty three frozen gastric biopsy and 56 saliva specimens were tested. $H$ pylori specific DNA was detected by PCR in all 39 culture positive biopsy specimens and was also identified from another seven biopsy specimens which were negative by culture but positive by histology. $H$ pylori specific DNA was identified by PCR in saliva specimens from $30(75 \%)$ of 40 patients with $H$ pylori infection demonstrated by culture or histological examination, or both, and in three patients without $H$ pylori infection in the stomach.

Conclusion-The results indicate that the oral cavity harbours $H$ pylori and may be the source of infection and transmission. (f Clin Pathol 1995;48:662-666)
\end{abstract}

Keywords: Helicobacter pylori, saliva, PCR.

Helicobacter pylori is now recognised as an important cause of active chronic gastritis in humans, plays a significant pathogenic role in the development and recurrence of gastric and duodenal ulcers, ${ }^{12}$ and perhaps gastric cancer. $^{3-5}$ The mode of transmission, the natural history and other aspects of the epidemiology of $H$ pylori infection are still unclear.

There is some evidence that the mouth may be a reservoir for $H$ pylori infection. In two studies from India using conventional microbiological techniques, $H$ pylori was present in the dental plaques of $100 \%$ of asymptomatic volunteers $^{6}$ and in $98 \%$ of dyspeptic subjects. ${ }^{7}$ In a report from Sweden, however, $H$ pylori was not recovered by culture from dental plaques or saliva from any of 52 patients who had culture positive gastric biopsy specimens. ${ }^{8}$

Polymerase chain reaction (PCR) protocols have recently been developed to detect $H$ pylori in clinical specimens. ${ }^{9-12}$ Using this technique, attempts to detect $H$ pylori DNA in dental plaque have been reported recently. From subjects whose gastric biopsy specimens were culture negative, $13(93 \%)$ of 14 adults $^{13}$ and $11(58 \%)$ of 19 children $^{14}$ were positive by PCR. In patients with proven gastric infection, $H$ pylori DNA was detected in seven $(39 \%)$ of $18^{15}$ and in two (13\%) of $13(15 \%),{ }^{16}$ respectively. As the primers used in these studies were derived from different genes, the results are difficult to evaluate.

We have recently developed a highly sensitive and specific DNA probe from chromosomal DNA of $H$ pylori. ${ }^{17}$ We have shown that the probe is very useful for typing $H$ pylori clinical isolates. ${ }^{1718}$ Here, we further report the development of a novel PCR assay based on the DNA sequence of our probe (Musich P R, Li C, 1994, unpublished data) and its use in the investigation of the prevalence of $H$ pylori in saliva. The results indicate that our PCR assay is a valuable tool for detecting $H$ pylori in saliva and could be used to elucidate the mode of transmission of infection.

\section{Methods}

SOURCE OF BACTERIAL STRAINS

The $H$ pylori strains used in this study included the American Type Culture Collection (ATCC) strain 43629 and $20 \mathrm{H}$ pylori isolates from human gastric biopsy specimens. ${ }^{17}$

Twenty three strains, including five Helicobacter spp, 12 closely related non-Helicobacter spp and four urease positive species not closely related to $H$ pylori, were used in specificity studies. They included: $H$ fennelliae (ATCC 35684); $H$ cinaedi (clinical isolate); $H$ heilmanii (ATCC 49286); $H$ felis (ATCC 49179); $H$ mustelae (ATCC 43772); Campylobacter concisus (ATCC 33237); $C$ sputorum subsp. sputorum (ATCC 35980); C sputorum subsp. bubulus (ATCC 33491); $C$ jejuni (two clinical isolates); $C$ coli (clinical isolate); $C$ lari (Skirrow, E152283); C upsaliensis (clinical isolate); $C$ fetus subsp. fetus (clinical isolate); $C$ rectus (VPI 10278B); Arcobacter cryaerophila (clinical isolate); Wolinella succinogenes (ATCC 29543); W. subsp. group 2 (VPI 10279); W. subsp. group 3 (VPI 10296); Escherichia coli (ATCC 25922); Klebsiella pneumoniae (clinical isolate); Morganella morganii (clinical isolate); and Proteus mirabilis (clinical isolate). The clinical isolates were obtained from the Clinical Microbiology Laboratory, Department of Microbiology, James $H$. Quillen College of Medicine, East Tennessee State University, and were isolated and identified by standard microbiological procedures. ${ }^{19}$ 
BIOPSY AND SALIVA SPECIMENS

Gastric biopsy specimens were obtained from 63 patients undergoing endoscopic examinations at the Veterans Affairs Medical Center, Johnson City, Tennessee, approved by the Institutional Research Board of East Tennessee State University. All biopsy specimens were cultured as described previously, ${ }^{17}$ examined histologically and stored at $-70^{\circ} \mathrm{C}$. Modified Steiner (silver) stain was used for identification of $H$ pylori in histological specimens. Saliva specimens $(1-2 \mathrm{ml})$ were collected from 56 of the 63 patients before undergoing endoscopy. The patients were asked to expectorate the saliva directly into new sterile containers containing digestion buffer $(100 \mathrm{mM} \mathrm{NaCl}$, $10 \mathrm{mM}$ Tris- $\mathrm{HCl}$ (pH 8.3), $250 \mathrm{mM}$ EDTA, and $1 \%$ sodium lauryl sarcosine). The saliva specimens were stored at $-70^{\circ} \mathrm{C}$.

\section{PREPARATION OF GENOMIC DNA FOR PCR}

ASSAY

Genomic DNA from $H$ pylori isolates and non$H$ pylori strains were prepared from freshly harvested bacterial cells as described previously. ${ }^{17}$

Each frozen gastric biopsy specimen was gently washed with TE buffer $(10 \mathrm{mM}$ Tris$\mathrm{HCl}, 1 \mathrm{mM}$ EDTA, $\mathrm{pH} 8.0$ ) and then transferred to an Eppendorf tube. The specimens were suspended in $100 \mu \mathrm{l}$ digestion buffer and $100 \mu \mathrm{g}$ proteinase $\mathrm{K}$ per $\mathrm{ml}$ and incubated at $55^{\circ} \mathrm{C}$ for three hours. The nucleic acids were extracted with an equal volume of phenol chloroform and precipitated with absolute ethanol. The DNA pellets were washed with $75 \%$ ethanol and finally resuspended in 50-100 $\mu \mathrm{l}$ TE buffer.

One volume of the digestion buffer and $100 \mu \mathrm{g}$ proteinase $\mathrm{K}$ per $\mathrm{ml}$ were added to the saliva samples and incubated at $55^{\circ} \mathrm{C}$ for three hours. The samples were then processed as for the DNA preparation from gastric biopsy specimens, described earlier.

\section{PCR PRIMERS}

Sequence data of the 0.86 kilobase DNA fragment (Musich P R, Li C, 1994, unpublished data) were used to select two 24 base oligonucleotide primers designated EHC-U (5'CCC TCA CGC CAT CAG TCC CAA AAA$\left.3^{\prime}\right)$ and EHC-L (5'-AAG AAG TCA AAA ACG CCC CAA AAC-3'). The oligonucleotides were synthesised at The Johns Hopkins University, School of Hygiene and Public Health, on the Eppendorf Synostat-D DNA Synthesiser and purified by a reverse phase high pressure liquid chromatography method. The expected product of amplification of the target sequence with these primers was 417 base pairs in length.

\section{PCR AMPLIFICATION}

Amplification was performed in $50 \mu \mathrm{l}$ reaction volumes containing the following: $0.5 \mu \mathrm{M}$ of each primer; $200 \mu \mathrm{M}$ (each) dATP, dCTP,
dTTP, and dGTP; $1 \times$ reaction buffer $(50 \mathrm{mM}$ $\mathrm{KCl}, 10 \mathrm{mM}$ Tris- $\mathrm{HCl}$ (pH 8.3), $1.5 \mathrm{mM}$ $\mathrm{MgCl}_{2}$, and $0.001 \% \mathrm{w} / \mathrm{v}$ gelatin); 1.25 units of Taq polymerase (Perkin-Elmer Cetus, Norwalk, Connecticut, USA); and $2 \mu$ l of DNA sample. Thirty cycles of amplification were performed in a DNA thermal cycler (GeneAmp PCR 9600 system, Perkin-Elmer Cetus). Each cycle consisted of a 45 second denaturation step at $94^{\circ} \mathrm{C}$, a 30 second annealing step at $59^{\circ} \mathrm{C}$ and a 45 second extension step at $72^{\circ} \mathrm{C}$. The final cycle included an extension step $\left(10\right.$ minutes at $72^{\circ} \mathrm{C}$ ) to ensure full extension of the product. Negative reagent control reactions were included in each batch of amplifications and consisted of tubes containing distilled water in place of the DNA samples.

\section{PREPARATION OF DNA PROBE}

The 417 base pair fragment was amplified from genomic DNA of $H$ pylori type strain ATCC 43629 by PCR with the EHC-U and EHC-L primers and used as the probe in Southern hybridisation. After amplification, the reaction mixtures were electrophoresed in $1.5 \%$ agarose gels and the 417 base pair fragments of interest were recovered from an agarose gel by electrophoresis onto DEAE-cellulose membrane (Nytran, NA-45, Schleicher \& Schuell, Keene, New Hampshire, USA). ${ }^{20}$ The DNA probe was labelled with ${ }^{32} \mathrm{P}$-dCTP (Amersham, Arlington Heights, Illinois, USA) by the Prime-a-Gene labelling system (Promega, Madison, Wisconsin, USA) to a specific activity of $1-2 \times 10^{9}$ $\mathrm{cpm} / \mu \mathrm{g}$ DNA.

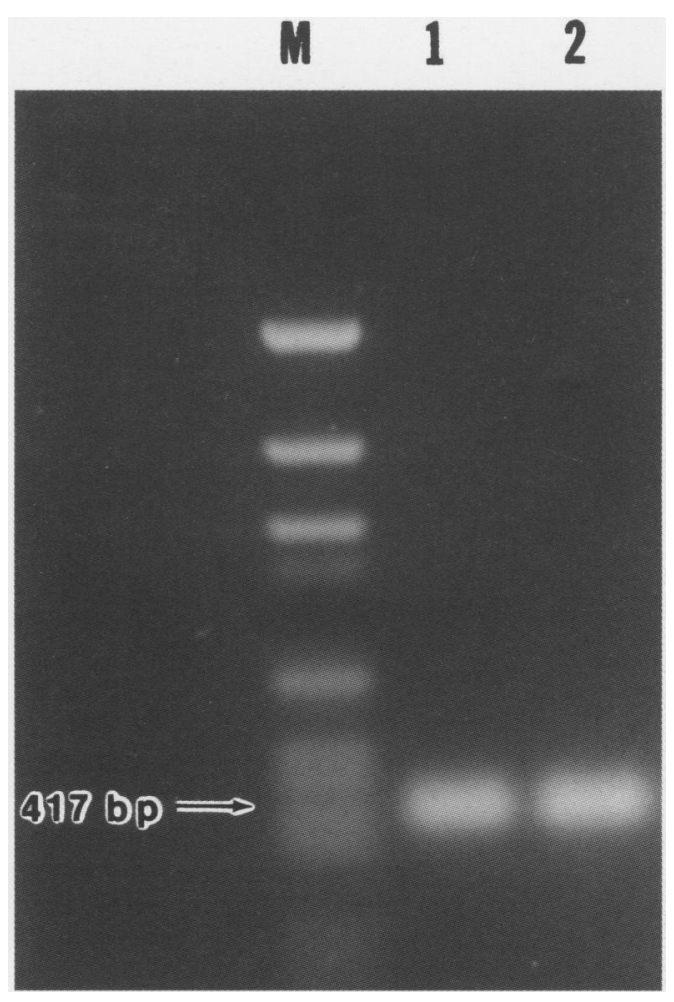

Figure 1 Agarose gel electrophoresis of the 417 base pair (bp) amplified PCR products from $H$ pylori ATCC 436219 (lane 1) and $p U C_{9}$ plasmid DNA containing the $0 \cdot 86$ kilobase fragment (lane 2). Lane $M$ contains a pGEM DNA marker (Promega). 
SOUTHERN BLOT HYBRIDISATION ANALYSIS

For identification of the amplified products, $10 \mu \mathrm{l}$ of the PCR reaction was analysed by electrophoresis on $1.5 \%$ agarose gels (SeaKem LE Agarose; FMC Products, Rockland, Maine, USA) and the amplified fragments were then transferred from the agarose gel to a nylon membrane (Nytran, Schleicher \& Schuell) by standard Southern blotting. ${ }^{20}$ The membranes were hybridised with the ${ }^{32} \mathrm{P}$-dCTP labelled DNA probe at the conditions described previously. ${ }^{17}$ The membranes were exposed to Kodak X-Omat XAR-5 film with intensifying screens for one to four hours at $-70^{\circ} \mathrm{C}$.

\section{Results}

DEVELOPMENT OF THE PCR ASSAY

By using the EHC-U and EHC-L primers, our PCR assay successfully amplified the expected product of 417 base pairs in size when either pUC $_{19}$ plasmid DNA containing 0.86 kilobase insert or genomic DNA from $H$ pylori type strain ATCC 43629 was used as a template (fig 1).
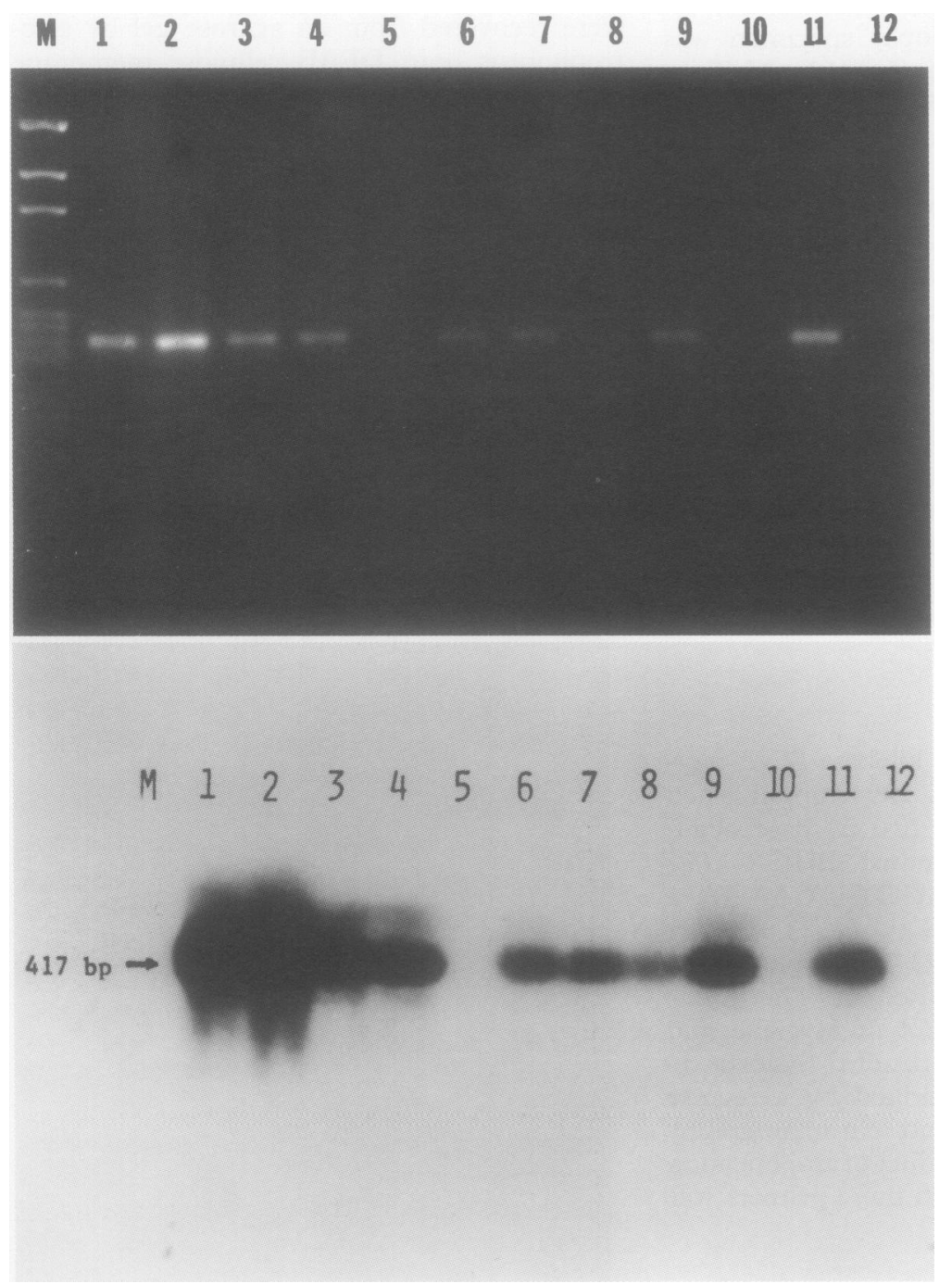

Figure 2 Detection of $H$ pylori in gastric biopsy specimens. The amplified products were analysed by agarose gel electrophoresis $(A)$ and Southern blot hybridisation $(B)$. Lane 1 , $H$ pylori ATCC 436219 (positive control); lanes 2-11, gastric biopsy specimens collected from 10 patients; lane 12, PCR negative control; lanes 5 and 10, gastric biopsy specimens from two patients which were negative for $H$ pylori infection on histological examination, culture and PCR.

\section{SENSITIVITY AND SPECIFICITY OF THE PCR} ASSAY

The sensitivity of PCR for detection of $H$ pylori sequences was tested by preparing serial dilutions of genomic DNA from $H$ pylori type strain ATCC 43629 . As little as $0 \cdot 1 \mathrm{pg}$ of genomic DNA generated a detectable 417 base pair fragment when $10 \mu$ of PCR reaction mixture was analysed by agarose gel electrophoresis. The sensitivity of the PCR assay for the detection of bacterial cells was also evaluated by using 10-fold dilutions of fresh $H$ pylori (ATCC 43629 ) bacterial cells. The number of bacterial cells per $\mathrm{ml}$ was estimated by means of McFarland nephelometer standards. The cells were then diluted with sterile distilled water and boiled for 15 minutes. PCR assay could detect as few as 10 cells when amplified products were analysed by Southern blot hybridisation. Our PCR assay also detected $H$ pylori specific DNA from all $21 H$ pylori clinical isolates when the amplified products were examined by agarose gel electrophoresis.

Twenty three genomic DNAs from five $\mathrm{Hel}$ icobacter spp ( $H$ mustelae, $H$ fennelliae, $H$ cinaedi, $H$ felis, and $H$ heilmanii), 14 closely related, non-Helicobacter spp and four urease positive species not closely related to $H$ pylori were used to test the specificity of our PCR assay. Twenty two of these strains showed no amplified products at an annealing temperature of $59^{\circ} \mathrm{C}$ when tested by agarose gel electrophoresis and Southern blot hybridisation. One strain ( $W$ succinogenes) generated a 500 base pair fragment which was detectable on agarose gel electrophoresis but was not detected by Southern blot hybridisation. When the annealing temperature was increased to $62^{\circ} \mathrm{C}$, however, no amplified product was detected from $W$ succinogenes by agarose gel electrophoresis. As $W$ succinogenes is restricted to bovine rumen and is not isolated from humans, use of PCR annealing temperature at $59^{\circ} \mathrm{C}$ is not epidemiologically significant.

PCR ASSAY OF GASTRIC BIOPSY SPECIMENS Gastric biopsy specimens obtained from 63 patients were tested by PCR assay, and the results were compared with those of histological examination (modified Steiner stain) and culture. PCR assay detected $H$ pylori specific DNA in all 39 culture positive biopsy specimens. Seven additional biopsy specimens which were negative by culture but positive by histology were also found to contain $H$ pylori specific DNA by PCR. The remaining $17 \mathrm{bi}-$ opsy specimens which were negative by both histology and culture were also negative by our PCR assay. Figure 2 shows a representative PCR result of the gastric biopsy specimens from 10 patients. Lanes 5 and 10 are PCR negative. The gastric biopsy specimens from these two patients were also negative for $H$ pylori infection as tested by histological examination and culture. 

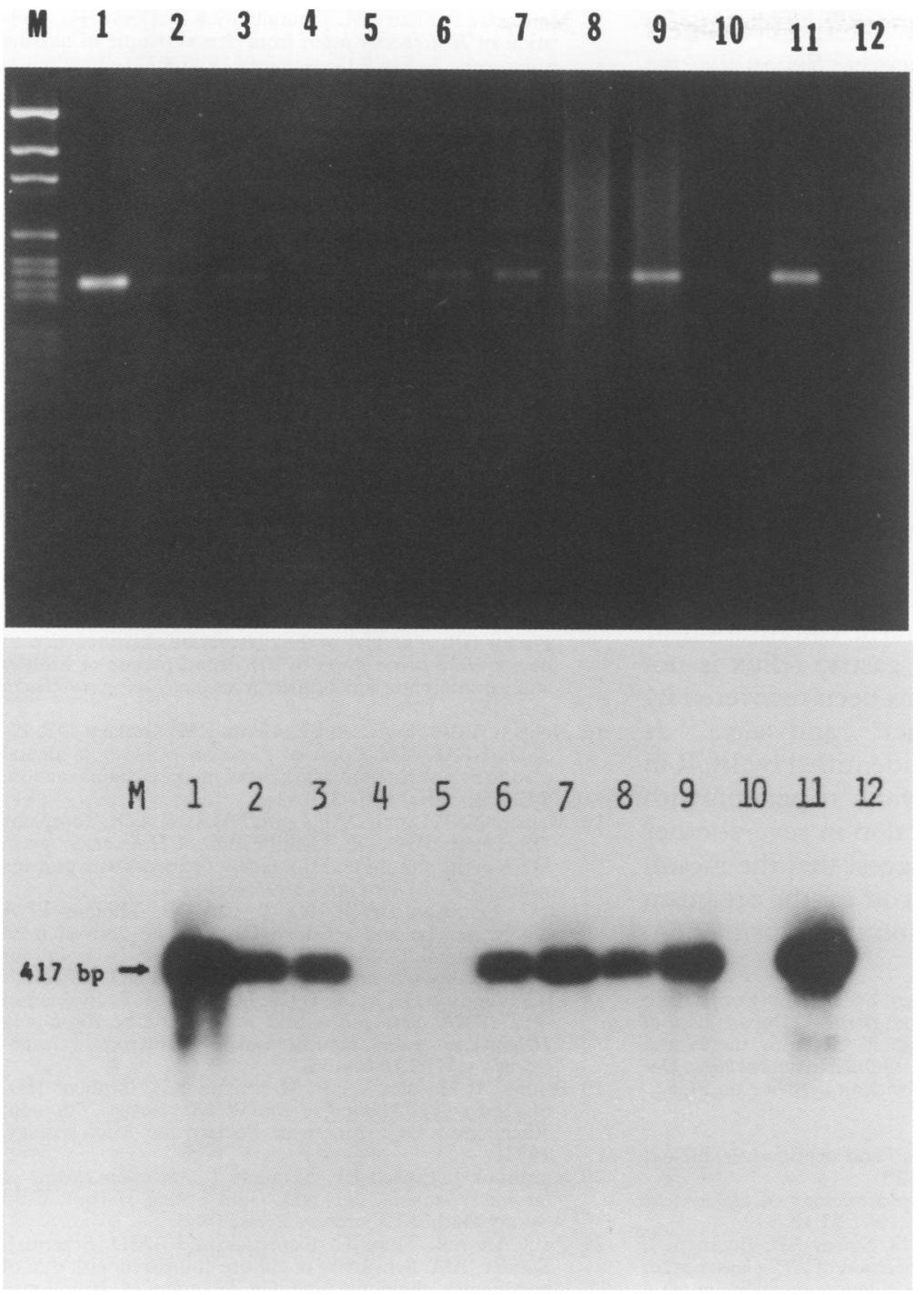

Figure 3 Detection of $H$ pylori in saliva specimens. The amplified products were analysed by agarose gel electrophoresis $(A)$ and Southern blot hybridisation (B). Lane 1, $H$ pylori ATCC 436219 (positive control); lanes 2-11, saliva specimens collected from the same 10 patients as shown in fig 2; lane 12, PCR negative control; lane 4, a PCR negative saliva specimen from a patient whose gastric biopsy specimen was positive for $H$ pylori infection; lanes 5 and 10, PCR negative saliva specimens from two patients whose gastric biopsy specimens were also negative for $H$ pylori infection.
PCR ASSAY OF SALIVA SPECIMENS

Saliva specimens were collected from 56 patients and tested by PCR. Forty of the 56 patients were shown to have $H$ pylori infection by culture, PCR and/or histological examination of their gastric biopsy specimens. The PCR assay detected $H$ pylori sequences in saliva specimens from 30 of these 40 patients and in saliva specimens from three other patients without gastric $H$ pylori infection. Figure 3 shows a representative PCR result of the saliva specimens from the same 10 patients as shown in fig 2. Lanes 5 and 10 are PCR negative for the saliva specimens from two patients whose gastric biopsy specimens were also negative for $H$ pylori as demonstrated by histological examination, culture and PCR assay. The negative PCR result in the lane 4 is from the saliva specimen of a patient whose gastric biopsy specimen was positive by culture and PCR assay.

\section{Discussion}

In this study a novel PCR assay for detecting $H$ pylori DNA in clinical specimens was developed using two 24 base oligonucleotide primers based on the sequence of the 0.86 kilobase fragment of chromosomal DNA of $H$ pylori (Musich P R, Li C, 1994, unpublished data).

Sixty three gastric biopsy specimens were tested for $H$ pylori specific DNA by our PCR assay. Good correlation between our PCR assay and culture/staining methods indicates that the PCR assay is sufficiently specific and sensitive to use for the detection of $H$ pylori in clinical specimens. Hammar et al ${ }^{12}$ reported that their PCR assay detected the presence of $H$ pylori in four biopsy specimens which were negative by culture. However, no information about the presence of $H$ pylori on histological staining was given. Clayton et al ${ }^{10}$ reported that $H$ pylor was detected by PCR in 15 of 23 clinical gastric biopsy samples. Only seven of these samples were positive for $H$ pylori on culture and microscopy. Mapstone et $a l^{16}$ found that eight patients with histologically normal gastric biopsy specimens had $H$ pylori DNA on PCR. It is difficult to compare these findings because of the use of different primers, PCR protocols and sampling techniques.

Valentine $e t a l^{9}$ and Zwet et $a l^{21}$ showed that the results of detection of $H$ pylori by culture were comparable with those of their PCR assay. In our study the PCR assay identified $H$ pylor from an additional seven biopsy specimens which were negative on culture but positive on histology. It is obvious that the PCR assay is more sensitive (46/63) than culture (39/63), which depends on the presence of viable organisms.

Recently, we have successfully isolated $H$ pylori from the saliva of one patient whose gastric biopsy specimen was positive on culture. ${ }^{22}$ This prompted us to use PCR to investigate the prevalence of $H$ pylori in saliva. Our PCR assay identified $H$ pylori specific DNA in $75 \%$ ( 30 of 40 ) of patients with proven gastric $H$ pylori infection. Hammar et al ${ }^{12}$ reported a $47 \%$ (nine of 19 ) detection rate of $H$ pylori specific DNA by PCR in saliva specimens from patients with proven $H$ pylori infection and Mapstone et $a l^{16}$ found $31 \%$ (three of 31 ) of saliva specimens to be positive on PCR. Our PCR assay had a higher rate of detection of $H$ pylori DNA in saliva (75\%) than these reports. This may be explained by our finding that the 0.86 kilobase DNA fragment used to develop our PCR assay may exist as multiple copies in the genomic DNA of $H$ pylori. ${ }^{22}$ Other possible explanations may be that (1) saliva specimens were directly collected into the digestion buffer in our protocols and (2) the whole saliva sample was used for extraction of DNA rather than pellets from saliva.

$H$ pylori DNA was identified by PCR in saliva specimens from three patients whose gastric biopsy specimens were negative for $H$ pylori on histological examination, culture and PCR. It is unlikely that these specimens were contaminated by extraneous $H$ pylori DNA for the following reasons. Firstly, the saliva specimens were collected by asking the patients to ex- 
pectorate directly into new sterile containers before undergoing endoscopy. Secondly, we performed sample collection, DNA extraction, pre-PCR preparation, and PCR amplification in separate rooms. Finally, we performed our PCR assay procedures using a minimum number of steps, used disposable tips and tubes, and regularly included negative controls with each test. There was no clear correlation between gastric symptoms and the presence of $H$ pylori DNA in the oral cavity. It is possible that oral colonisation by $H$ pylori may precede gastric infection. The possibility of such oral colonisation is supported by the observation of $H$ pylori in the dental plaque of children at a much higher frequency than had been previously reported in the literature. ${ }^{14}$

Whether the $H$ pylori DNA we have detected in saliva represents long term colonisation or sporadic reinfection from gastric reflux is not clear. However, $H$ pylori has been recovered by culture from dental plaques ${ }^{623}$ and saliva. ${ }^{22} H$ pylori DNA has also been identified by PCR in dental plaques ${ }^{13-15}$ and saliva ${ }^{1216}$ of patients with and without $H$ pylori infection in several other studies. These findings suggest that the mouth may be a permanent reservoir for the organism and a source of both infection and transmission.

This project was supported in part by a grant from Glaxo Research Institute. We thank Betty Barnett, Department of Microbiology, for her technical skill in preparing media and reagents for this study. We thank Guha Krishnaswamy, Department of Internal Medicine, for technical advice on PCR.

1 Graham DY. Campylobacter pylori and peptic ulcer disease. Gastroenterology 1989;96:615-25.

2 Taylor DN, Blaser MJ. The epidemiology of Helicobacter pylori infection. Epidemiol Rev 1991;13:42-59.

3 Forman D, Sitas F, Newell DG, Stacey AR, Boreham J, Peto R, et al. Geographic association of Helicobacter pylor antibody prevalence and gastric cancer mortality in rura China. Int $\mathcal{F}$ Cancer 1990;46:608-11.

4 Forman D, Newell DG, Fullerton F, Yarnell JWG, Stacey $\mathrm{AR}$, Wald N, et al. Association between infection with Helicobacter pylori and risk of gastric cancer: evidence from a prospective investigation. BMF 1991;302:1302-5

5 Parsonnet J, Vandersteen D, Goates J, Sibley RK, Pritikin $\mathrm{J}$, Chang Y. Helicobacter pylori infection in intestinal- and diffuse-type gastric adenocarcinomas. F Natl Cancer Inst diffuse-type gas
6 Majmudar P, Shah SM, Dhunjibhoy KR, Desai HG. Isolation of Helicobacter pylori from dental plaque in healthy volunteers. Indian 7 Gastroenterol 1990;4:271-2.

7 Desai HG, Gill HH, Shankaran K, Mehta PR, Prabhu SR. Dental plaque: a permanent reservoir of Helicobacter pylori. Scand $f$ Gastroenterol 1991;26:1205-8.

8 Bernander S, Dalen J, Gastrin B, Hedenborg L, Lamke LO, Ohrn R. Absence of Helicobacter pylori in dental plaques Ohrn R. Absence of Helicobacter pylori in dental plaques
in Helicobacter pylori positve dyspeptic patients. Eur 7 Clin in Helicobacter pylori positve dyspeptic

9 Valentine JL, Arthur RR, Mobley HLT, Dick JD. Detection of Helicobacter pylori by using the polymerase chain reaction. F Clin Microbiol 1991;29:689-95.

10 Ho SA, Hoyle JA, Lewis FA, Secker AD, Cross D, Mapstone $\mathrm{NP}$, et al. Direct polymerase chain reaction test for detection of Helicobacter pylori in humans and animals. 7 Clin Microbiol 1991;29:2543-9.

11 Clayton CL, Kleanthous H, Coates PJ, Morgan DD, Tabaqchali S. Sensitive detection of Helicobacter pylori by using polymerase chain reaction. f Clin Mircobiol 1992; using polym

12 Hammer M, Tyszkeiwicz T, Wadstrom T, O'Toole PW. Rapid detection of Helicobacter pylori in gastric biopsy material by polymerase chain reaction. 7 Clin Microbiol 1992;30:54-8.

13 Olsson K, Wadstrom T, Tyszkiewicz T. $H$ pylori in dental plaques [letter]. Lancet 1993;341:956-67.

14 Banatvala N, Lopez CR, Owen RJ, Hurtado A, Abdi Y, Davies GR, et al. Use of the polymerase chain reaction to detect Helicobacter pylori in the dental plaque of healthy and symptomatic individuals. Microbial Ecology in Health and Disease 1994;7:1-8.

15 Nguyen AMH, Engstrand L, Genta RM, Graham DY, ElZaatari FAK. Detection of Helicobacter pylori in dental plaque by reverse transcription-polymerase chain reaction. plaque by reverse transcription-p
f Clin Microbiol 1993;31:783-7.

16 Mapstone NP, Lynch DAF, Lewis FA, Axon ATR, Tompkins DS, Dixon MF, et al. Identification of Helicobacter pylori DS, Dixon MF, et al. Identification of Helicobacter pylori DNA in the mouths and stomachs of patients
using PCR. $\mathcal{F}$ Clin Pathol 1993;46:540-3.

$17 \mathrm{Li} \mathrm{C}$, Ferguson DA Jr, Ha T, Chi DS, Thomas E. A highly specific and sensitive DNA probe derived from chromosomal DNA of Helicobacter pylori is useful for typing $H$. pylori isolates. F Clin Microbiol 1993;31:2157-62.

$18 \mathrm{LiC}$, Ferguson DA Jr, Ha T, Chi DS, Thomas E. Evaluation of a rRNA gene probe and a DNA probe for typing Helicobacter pylori clinical isolates [abstract]. Gastroenterology 1993;104:A133.

19 Balows A, Hausler WJ Jr, Herrmann KL, Isenberg HD, Shadomy HJ. Manual of clinical microbiology. 5th edn. Washington DC: American Society for Microbiology, 1991.

20 Sambrook J, Fritsch EF, Maniatis T. Molecular cloning: a laboratory manual. 2nd edn. Cold Spring Harbor: Cold Spring Harbor Laboratory Press, 1989.

21 Zwet AA van, Thijs JC, Kooistra-Smid AMD, Schirm J, Snijder JAM. Sensitivity of culture compared with that of polymerase chain reaction for detection of Helicobacter pylori from antral biopsy samples. F Clin Microbiol 1993; 31:1918-20.

22 Ferguson DA Jr, Li C, Patel NR, Mayberry WR, Chi DS, Thomas E. Isolation of Helicobacter pylori from saliva. $\mathcal{f}$ Clin Microbiol 1993;31:2802-4.

23 Krajen S, Fuksa M, Anderson J, Kempston J, Boccia A, Petrea C, et al. Examination of human stomach biopsies, saliva, and dental plaque for Campylobacter pylori. $\mathcal{F}$ Clin Microbiol 1989;31:1397-8. 